\title{
Growth and Decomposition of Millets in Odisha: 1960-61 to 2019-20
}

\begin{abstract}
Background: Odisha started a programme to revive millets in 2017. Keeping this in the background, this paper examines growth of production, area and yield and decomposition of production of millets in Odisha in the last six decades by using triennium ending data, TE1962-63 to TE2019-20.

Methods: Boyce's kinked exponential method has been used to estimate growth for production, area and yield. Production was decomposed to area, yield and interaction effects. Millets as a crop group is compared with other foodgrain groups and then analysis was carried out for four specific millet crops - ragi, jowar, bajra and small millets.

Result: In Odisha, the 1960s and 1970s indicate an increasing trend in production of and area under millets. There is a reversal of these trends since 1980s. The decline started first for small millets in the 1980s and subsequently since the 1990s for the three major millets - bajra, jowar and ragi. Decomposition of millets production indicates that the decline since 1980s is largely on account of area effect, but also because of yield effect in the 1990s and 2010s.
\end{abstract}

Key words: Decomposition, Foodgrains, Growth, Millets, Production.

\section{INTRODUCTION}

Millets are sturdier and hardier crops that can survive in rocky soils and in areas of scanty rainfall and with harsh climatic conditions (Gari 2002) and also occupy an essential role in the diet of people in many regions of the world (Anderson and Martin 1949). Besides, compared to other cereals like rice and wheat, millets have better nutritional characteristics and health benefits (FAO 1995; Bhat et al. 2018; Datir et al. 2018; Goel et al. 2021; Rana and Dahiya 2021). Asia and Africa are the major producers of millets of the world (FAO and ICRISAT 1996; Rao et al. 2017). Millets are cultivated and consumed as a major staple food by many of the poorest countries in Sub-Saharan Africa (Ahmed et al. 2000) and by the marginal farmers and tribals under rainfed condition in developing countries like India (Basavaraj et al. 2010). Likewise, the indigenous tribal in the southern districts of Odisha also cultivate and consume millets, where food and nutrient security are the key issues (Government of Odisha 2016a). Conventionally, it is often referred to as coarse cereals, but realizing the nutrient richness of the grains, it is now considered as nutri-cereals (Government of India 2018) or smartfood (ICRISAT 2019).

Post green-revolution, based on data obtained from EPWRF's India time series, the area under foodgrains increased from 124.32 million hectares in 1970-71 to 126.99 million hectares in 2019-20. However, the area under millets decreased from 37.53 million hectares in 1970-71 to 13.82 million hectares in 2019-20 (see Fig 1 for triennium ending trends in area and production) and the area under non-millet cereals increased from 61.68 million hectares to 84.59 million hectares and that for pulses increased from 22.54 million hectares to 27.99 million hectares.
${ }^{1}$ Nabakrushna Choudhury Centre for Development Studies, Bhubaneswar-751 013, Odisha, India.

${ }^{2}$ Indira Gandhi Institute of Development Research, Goregaon East, Mumbai-400 065, Maharashtra, India.

Corresponding Author: S. Mishra, Indira Gandhi Institute of Development Research, Goregaon East, Mumbai-400 065, Maharashtra, India. Email: srijit@igidr.ac.in

How to cite this article: Jena, D. and Mishra, S. (2022). Growth and Decomposition of Millets in Odisha: 1960-61 to 2019-20. Agricultural Science Digest. DOI: 10.18805/ag.D-5447.

Submitted: 10-07-2021 Accepted: 07-12-2021 Online: 07-01-2022

In Odisha where the green-revolution ushered in at a later period (late 70 s to early $80 \mathrm{~s}$ ) the area under foodgrains decreased from 6.91 million hectares in 1980-81 to 6.26 million hectares in 2019-20 (Government of Odisha 2020). This was on account of decreased area under millets from 0.74 million hectares in $1980-81$ to 0.16 million hectares in 2019-20 and decreased area under non-millet cereals from 4.44 million hectares to 4.18 million hectares. At the same time, area under pulses increased from 1.73 million hectares to 1.92 million hectares.

Recently, a resolution sponsored by India and supported by more than 70 countries to declare 2023 as the 'International year of Millets' has also been adopted by the United Nations. The Government of Odisha also has launched a "Special Programme for Promotion of Millets in Tribal Areas of Odisha," also referred to as Odisha Millets Mission (OMM), in 2016-17, which has been operating through four verticals - production, processing, marketing and consumption, Government of Odisha (2016b). Keeping 
these in the background, the present study proposes to examine growth of production, area and yield and decomposition of production of millets in Odisha.

\section{MATERIALS AND METHODS}

Data from 1960-61 to 2019-20 is based on Odisha's agricultural statistics (Government of Odisha 2020). The data was first smoothened by a three-year moving average and then the triennium ending (TE) data was used as six decadal subperiods: 1960s, TE1962-63 to TE1970-71; 1970s, TE197071 to TE1980-81; 1980s, TE1980-81 to TE1990-91; 1990s, TE1990-91 to TE2000-2001; 2000s, TE2000-01 to TE201011 and 2010s, TE2010-11 to TE2019-20. The major foodgrains grown in Odisha have been categorized into three groups: millets (ragi, jowar, bajra and small millets), non-millet cereals (rice, wheat and maize) and pulses.

Growth rates for production, area and yield are estimated using kinked exponential model of Boyce (1986),

$$
\begin{gathered}
\ln Z_{t}=\alpha+\beta_{1}\left(D_{1} t+\sum_{j=2}^{m} D_{j} K_{1}\right)+\beta_{2}\left(D_{2} t-\sum_{j=2}^{m} D_{j} K_{1}+\right. \\
\left.\sum_{j=3}^{m} D_{j} K_{2}\right)+. .+\beta_{i}\left(D_{i} t-\sum_{j=i}^{m} D_{j} K_{i-1}+\sum_{j=i+1}^{m} D_{j} K_{i}\right)+. .+ \\
\beta_{m}\left(D_{m} t-D_{m} K_{m-1}\right)+u_{t}
\end{gathered}
$$

In equation (1), In is natural logarithm, $Z_{t}$ denotes production, $P_{t}$, area, $A_{t}$ and yield, $Y_{t}=P_{t} / A_{t}$, of crop groups, $t=1, \ldots, T$ is triennium ending time points with $i=1, \ldots, m$ subperiods and $\mathrm{m}-1$ kinks where $\mathrm{K}_{1}, . ., \mathrm{K}_{\mathrm{m}-1}$ are kink points, $\mathrm{D}_{1}$, .., $D_{m}$ are dummy variables, $\alpha$ is intercept, $\beta_{\mathrm{i}}$ 's are growth estimates and $u_{t}$ is an error term.

Following Narain (1977) decomposition of production has been analysed into area, yield and interaction effects,

$$
\Delta P_{t}=\Delta A_{t} Y_{t-\tau}+\Delta Y_{t} A_{t-\tau}+\Delta A_{t} \Delta Y_{t}
$$

Where,

$\Delta \mathrm{Z}_{\mathrm{t}}=\mathrm{Z}_{\mathrm{t}}-\mathrm{Z}_{\mathrm{t}-\tau} ; \tau=1, \ldots, \mathrm{t}-1$ denotes change at time $\mathrm{t}$ with respect to time, $\mathrm{t}-\tau$.

\section{RESULTS AND DISCUSSION}

Decade-wise kinked exponential growth rate for production, area and yield of foodgarin groups in Odisha is given in Table 1 . The statistically significant results for production, area and yield, are discussed below.

\section{Foodgrains production}

For millets, production growth was positive and significant in 1960s and 1970s and it has been negative since the 1980s and this negative growth was significant in 1990s and 2010s and the latter also resonates with negative production growth for millets in the post-liberalisation period, Fig 2 and Paltasingh and Goyari (2013). For non-millet cereals (which includes paddy), production growth was positive and significant in 1980s, 2000s and 2010s. For pulses, production growth was positive and significant in 1970s, 1980 s and 2000s and negative and significant in 1990s and 2010s.

\section{Foodgrains area}

For millets, area growth was positive and significant in 1960s and 1970s and has been negative and significant in each of the subsequent four decades since 1980s. The observation of Bhalla and Singh (2009) and Malathi et al. (2016) that there has been a shift away from millets in eastern states since 1980s is also evident for Odisha in our analysis. For non-millet cereals, growth of area was positive and significant in 1960s and 1990s and was negative and significant in 2010s. For pulses, area growth was positive and significant in the first three decades from 1960s to 1980s and was negative and significant in 1990s and 2010s.

\section{Foodgrains yield}

For millets, yield growth has been alternating, it was positive and significant in 1960s, 1980s and 2000s and was negative and significant in 1970s and 1990s, see Fig 2. For non-

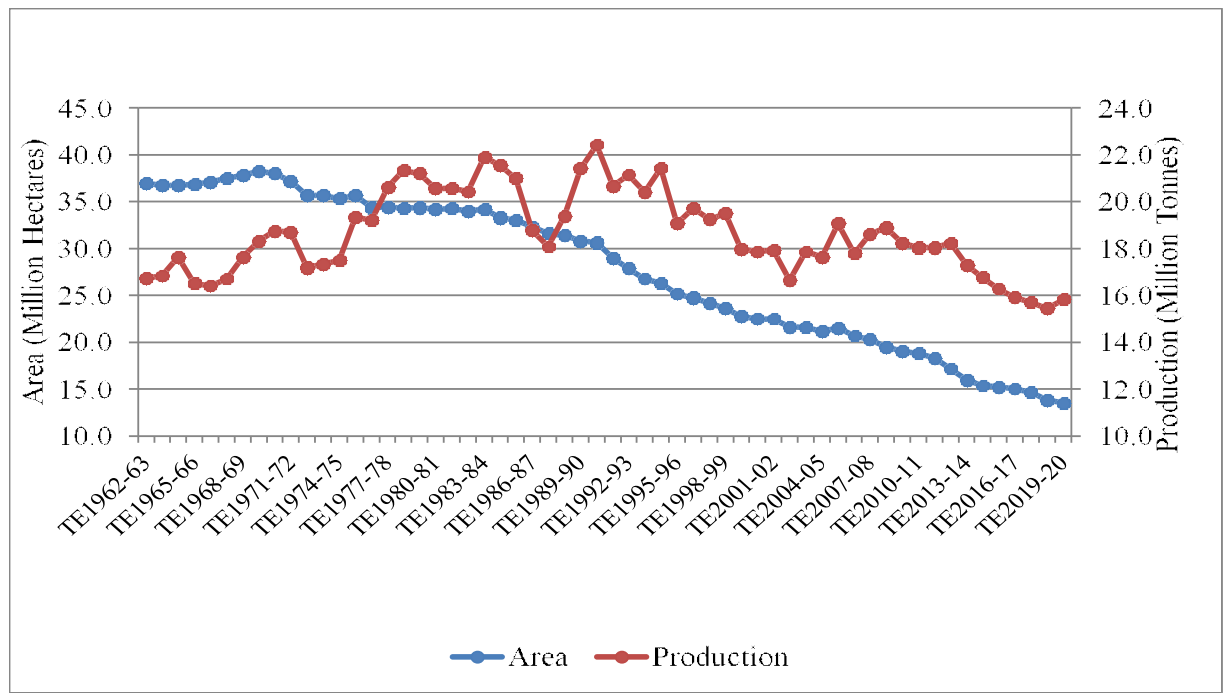

Fig 1: Trends in area and production of millets in India. Source: EPW Research Foundation. 


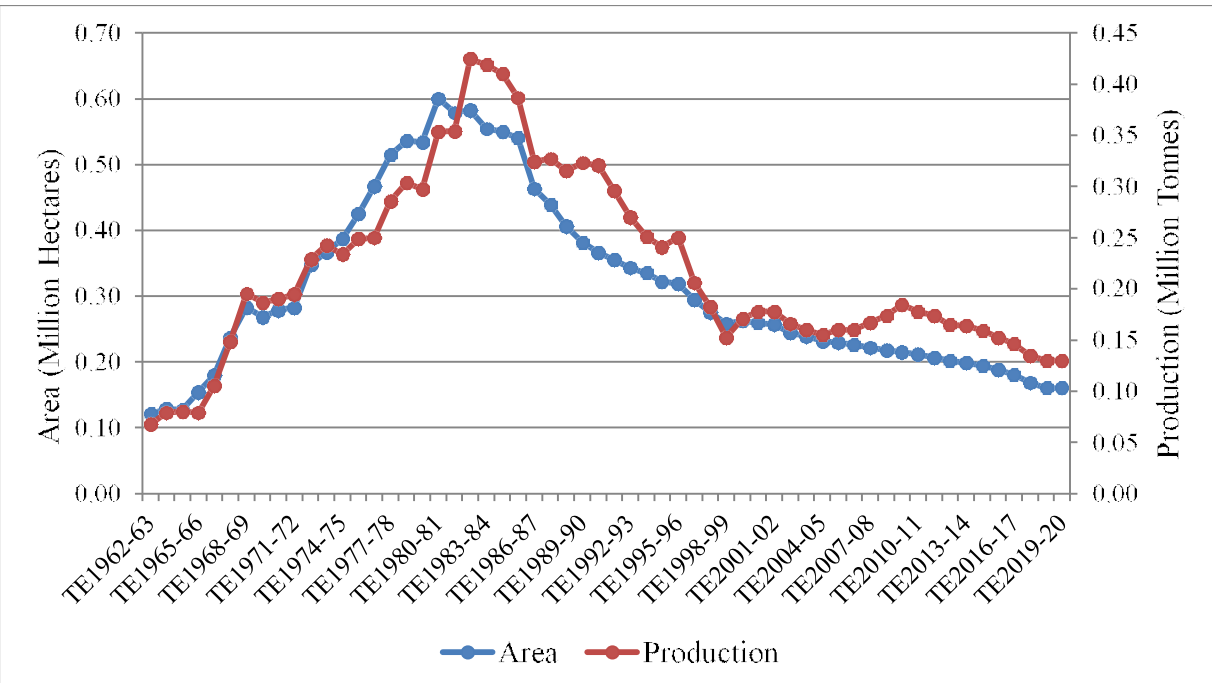

Fig 2: Trends in area and production of millets in Odisha.

Source: Odisha Agriculture Statistics, Directorate of Agriculture and Food Production, Odisha.

Table 1: Kinked exponential growth in production, area and yield of foodgrains in Odisha (\%).

\begin{tabular}{llrrrrrr}
\hline Item & Foodgrains & $1960 \mathrm{~s}$ & $1970 \mathrm{~s}$ & $1980 \mathrm{~s}$ & $1990 \mathrm{~s}$ & $2000 \mathrm{~s}$ & $2010 \mathrm{~s}$ \\
\hline Production & Millets & $15.28^{*}$ & $4.45^{*}$ & -0.11 & $-7.40^{*}$ & -0.16 & $-7.65^{*}$ \\
& Non-millet cereals & 0.95 & -0.29 & $4.35^{*}$ & -0.57 & $3.25^{*}$ & $1.95^{*}$ \\
& Pulses & 1.66 & $4.38^{*}$ & $7.10^{*}$ & $-7.94^{*}$ & $3.07^{*}$ & $-2.92^{*}$ \\
Area & Millets & $13.72^{*}$ & $5.41^{*}$ & $-3.95^{*}$ & $-3.66^{*}$ & $-3.84^{*}$ & $-8.02^{*}$ \\
& Non-millet cereals & $0.86^{*}$ & 0.00 & 0.00 & $0.01^{*}$ & -0.01 & $-0.01^{*}$ \\
& Pulses & $2.25^{*}$ & $4.47^{*}$ & $4.55^{*}$ & $-3.16^{*}$ & 0.78 & $-4.22^{*}$ \\
Yield & Millets & $1.96^{*}$ & $-0.96^{*}$ & $3.89^{*}$ & $-3.36^{*}$ & $3.21^{*}$ & 0.61 \\
& Non-millet cereals & -0.28 & -0.30 & $4.33^{*}$ & $-1.40^{*}$ & $4.03^{*}$ & $3.47^{*}$ \\
& Pulses & 0.80 & -0.45 & $2.55^{*}$ & $-4.49^{*}$ & $1.92^{*}$ & $2.09^{*}$ \\
\hline
\end{tabular}

Note: *Significant at 95\% confidence interval. Source: Authors' estimates based on Government of Odisha (2020).

millet cereals and pulses yield growth rate followed a similar pattern of being positive and significant in 1980s, 2000s and 2010s and of being negative and significant in 1990s. The 1990s was a decade of negative growth for all three foodgrain groups in yield and for millets and pulses in production and area as well. Except for this digression in 1990s, the patterns supports the contention of Bhalla and Singh (2009) that the impact of green revolution technology increasing yield for rice and wheat, initially confined to irrigated states, mostly in the north-western parts of India, spread to other parts since 1980s also holds for Odisha.

Decomposition of production for three foodgrain groups in Odisha from 1960s to 2010s is given in Table 2. It shows area, yield and interaction effects of production change in millets, non-millet cereals and pulses. The production change may not mimic the production growth rates as the latter is computed using all the years in the sub-period while decomposition uses the base and end years only. For millets, the increase in production was on account of all three effects in 1960s, area effect in 1970s and yield effect in 2000s, while the decrease in production was on account of area and interaction effects in 1980s and 2010s and area and yield effects in 1990s. For non-millet cereals, the increase in production was on account of all three effects in 1960s and 1980s and yield effect in 2000s and 2010s, while the decrease in production was on account of area and yield effects in 1970s and yield and interaction effects in 1990s. For pulses, the increase in production was on account of all three effects in 1960s, 1980s and 2000s, area effect in 1970s and yield effect in 2010s, while the decrease in production was on account of area and yield effects in 1990s.

The growth rates in production, area and yield for three major millet crops (ragi, jowar and bajra) and small millets is given in Table 3 .

\section{Milets production}

For ragi, production growth was positive and significant for the first three decades from 1960s to 1980s and was negative and significant in 1990s and 2010s. For jowar, production growth was positive and significant in 1960s and 1970 s and was negative and significant from 1990s to 2010 s. For bajra, production growth has been positive and significant in 1970s and 1980s and has been negative and 
significant in 1960s and in the last three decades. For small millets, production growth was positive and significant in 1960s and 1970s and has been negative and significant for the subsequent three decades from 1980s to 2000 s.

\section{Milets area}

In 1960s and 1970s, area growth was similar to production growth, positive and significant for all four millet crops, except for negative and significant growth for bajra in 1960s. The area growth has been negative and significant for ragi, jowar and bajra for the last three decades from 1990s to 2010s. For small millets, area growth has been negative and significant for three decades from 1980s to 2000s and there seems to be a revival with area growth being positive and significant in 2010s.

\section{Milets yield}

For ragi, yield growth was positive and significant in 1960s, 1980 s and the last two decades, 2000s and 2010s. For jowar and bajra, yield growth has been positive and significant in 1980s and negative and significant in 1990s. For small millets, yield growth was positive and significant in 1970s and 1980s and was negative and significant in 1960s and 1990s.
Decomposition of production of millet crops in Odisha from 1960s to 2010 s is given in Table 4. It shows area, yield and interaction effects of production change in each millet crop. For ragi, the increase in production was on account of all three effects in 1960s, area effect in 1970 and yield effect in 1980s and 2000s and the decrease in production was on account of area and yield effects in 1990s and area and interaction effects in 2010s. For jowar, the increase in production was on account of all three effects in 1960s, area effect in 1970s and yield effect in 1980s and the decrease in production was on account of area and yield effects in 1990s and area and interaction effects in 2000s and 2010s. For bajra, the increase in production was on account of all three effects in 1970s and yield effect in 1980s and the decrease in production was on account of area and yield effects in 1990s and area and interaction effects in 1960s, 2000s and 2010s. For small millets, the increase in production was on account of all three effects in 1970s and 2010s and area effect in 1960s and the decrease in production was on account of area and interaction effects in 1980s and 2000s and area and yield effects in 1990s. The broad patterns for jowar and bajra in the last four

Table 2: Decomposition of change in production of foodgrains in Odisha to area, yield and interaction effects.

\begin{tabular}{|c|c|c|c|c|c|c|c|}
\hline Foodgrains & Effect & $1960 \mathrm{~s}$ & 1970 s & $1980 s$ & $1990 \mathrm{~s}$ & $2000 s$ & $2010 s$ \\
\hline \multirow[t]{4}{*}{ Millets } & Area, \% & 72.23 & 134.07 & 415.60 & 66.03 & -88377.07 & 103.42 \\
\hline & Yield, \% & 12.06 & -15.80 & -516.54 & 48.11 & 108225.05 & -4.63 \\
\hline & Interaction, \% & 15.71 & -18.27 & 200.94 & -14.15 & -19747.98 & 1.21 \\
\hline & $\Delta \mathrm{P}, ‘ 000 \mathrm{MT}$ & 122.13 & 163.67 & -33.09 & -142.67 & 0.04 & -44.93 \\
\hline \multirow[t]{4}{*}{ Non-millet cereals } & Area, \% & 73.23 & 36.96 & 6.83 & -25.84 & -4.02 & -69.36 \\
\hline & Yield, \% & 24.25 & 63.92 & 90.50 & 122.66 & 105.82 & 189.91 \\
\hline & Interaction, \% & 2.52 & -0.89 & 2.68 & 3.18 & -1.81 & -20.55 \\
\hline & $\Delta \mathrm{P}, \mathrm{CO00} \mathrm{MT}^{\mathrm{M}}$ & 529.61 & -159.87 & 1778.16 & -590.70 & 2249.61 & 1176.51 \\
\hline \multirow[t]{4}{*}{ Pulses } & Area, \% & 64.11 & 138.13 & 46.40 & 52.74 & 52.13 & -55.01 \\
\hline & Yield, \% & 28.39 & -20.31 & 43.26 & 63.24 & 35.50 & 161.59 \\
\hline & Interaction, \% & 7.50 & -17.81 & 10.34 & -15.97 & 12.37 & -6.58 \\
\hline & $\Delta \mathrm{P},{ }^{\prime} 000 \mathrm{MT}$ & 133.57 & 290.53 & 385.34 & -542.91 & 394.71 & 72.94 \\
\hline
\end{tabular}

Source: Authors' estimates based on Government of Odisha (2020).

Table 3: Kinked exponential growth in production, area and yield of millet crops in Odisha (\%).

\begin{tabular}{|c|c|c|c|c|c|c|c|}
\hline Item & Crop & $1960 \mathrm{~s}$ & $1970 \mathrm{~s}$ & $1980 \mathrm{~s}$ & $1990 \mathrm{~s}$ & $2000 s$ & 2010s \\
\hline \multirow[t]{4}{*}{ Production } & Ragi & $17.68^{*}$ & $3.13^{*}$ & $2.37^{*}$ & $-6.02^{*}$ & 1.09 & $-7.35^{\star}$ \\
\hline & Jowar & $16.40^{*}$ & $7.19^{*}$ & 0.89 & $-11.88^{*}$ & $-5.80^{*}$ & $-11.11^{*}$ \\
\hline & Bajra & $-5.47^{*}$ & $11.35^{*}$ & $5.61^{*}$ & $-13.86^{*}$ & $-4.78^{*}$ & $-14.36^{\star}$ \\
\hline & Small millets & $13.25^{*}$ & $5.79^{*}$ & $-8.48^{*}$ & $-9.42^{*}$ & $-10.92^{*}$ & 2.53 \\
\hline \multirow[t]{4}{*}{ Area } & Ragi & $12.15^{*}$ & $5.43^{*}$ & -0.79 & $-2.47^{*}$ & $-2.38^{*}$ & $-9.62^{*}$ \\
\hline & Jowar & $15.25^{*}$ & $6.37^{*}$ & -0.52 & $-7.58^{*}$ & $-7.02^{*}$ & $-10.28^{*}$ \\
\hline & Bajra & $-7.80^{*}$ & $10.00^{*}$ & 0.19 & $-7.20^{*}$ & $-6.65^{*}$ & $-13.42^{*}$ \\
\hline & Small millets & $17.35^{*}$ & $4.87^{*}$ & $-10.28^{*}$ & $-6.64^{*}$ & $-12.52^{*}$ & $3.89^{*}$ \\
\hline \multirow[t]{4}{*}{ Yield } & Ragi & $5.54^{*}$ & $-1.97^{*}$ & $3.05^{*}$ & $-3.67^{*}$ & $3.42^{*}$ & $2.50^{*}$ \\
\hline & Jowar & 1.27 & 0.54 & $1.57^{*}$ & $-4.12^{*}$ & 0.86 & -0.17 \\
\hline & Bajra & 2.15 & 1.43 & $5.32^{*}$ & $-6.55^{\star}$ & 1.78 & -1.45 \\
\hline & Small millets & $-4.94^{*}$ & $1.13^{*}$ & $2.25^{*}$ & $-3.12^{*}$ & 0.92 & -0.79 \\
\hline
\end{tabular}

Note: *Significant at 95\% confidence interval. Source: Authors' estimates based on Government of Odisha (2020). 
Table 4: Decomposition of change in production of millet crops in Odisha to area, yield and interaction effects.

\begin{tabular}{|c|c|c|c|c|c|c|c|}
\hline Crop & Effect & $1960 \mathrm{~s}$ & $1970 \mathrm{~s}$ & $1980 \mathrm{~s}$ & $1990 \mathrm{~s}$ & $2000 \mathrm{~s}$ & $2010 s$ \\
\hline \multirow[t]{4}{*}{ Ragi } & Area, \% & 47.25 & 176.88 & -70.31 & 52.33 & -100.33 & 116.60 \\
\hline & Yield, \% & 23.93 & -39.26 & 198.96 & 60.29 & 218.05 & -26.04 \\
\hline & Interaction, \% & 28.82 & -37.62 & -28.65 & -12.62 & -17.72 & 9.44 \\
\hline & $\Delta \mathrm{P},{ }^{\prime} 000 \mathrm{MT}$ & 96.39 & 72.71 & 42.38 & -99.73 & 12.11 & -50.28 \\
\hline \multirow[t]{4}{*}{ Jowar } & Area, \% & 96.26 & 108.97 & -99.95 & 79.85 & 123.50 & 103.36 \\
\hline & Yield, \% & 1.71 & -4.69 & 217.23 & 41.82 & -35.87 & -4.84 \\
\hline & Interaction, \% & 2.03 & -4.28 & -17.27 & -21.67 & 12.37 & 1.48 \\
\hline & $\Delta \mathrm{P},{ }^{\prime} 000 \mathrm{MT}$ & 6.14 & 9.31 & 1.63 & -14.31 & -2.16 & -1.65 \\
\hline \multirow[t]{4}{*}{ Bajra } & Area, \% & 158.06 & 93.93 & -60.89 & 73.92 & 153.77 & 102.85 \\
\hline & Yield, \% & -116.14 & 1.77 & 192.24 & 50.31 & -66.59 & -4.48 \\
\hline & Interaction, \% & 58.08 & 4.30 & -31.34 & -24.23 & 12.82 & 1.63 \\
\hline & $\Delta \mathrm{P},{ }^{\prime} 000 \mathrm{MT}$ & -0.62 & 3.46 & 1.28 & -3.96 & -0.27 & -0.65 \\
\hline \multirow[t]{4}{*}{ Small millets } & Area, \% & 194.69 & 79.05 & 108.57 & 80.86 & 113.79 & 95.90 \\
\hline & Yield, \% & -34.88 & 8.61 & -28.69 & 35.72 & -34.48 & 2.22 \\
\hline & Interaction, \% & -59.81 & 12.33 & 20.12 & -16.58 & 20.69 & 1.88 \\
\hline & $\Delta \mathrm{P}, ' 000 \mathrm{MT}$ & 20.21 & 78.19 & -78.38 & -24.67 & -9.65 & 7.65 \\
\hline
\end{tabular}

Source: Authors' estimates based on Government of Odisha (2020).

decades and for small millets in 1990s and 2000s were similar. Our analysis of growth and decomposition is perhaps indicative that there is an unmet demand for small millets.

In this context, one may appreciate the fact that the Government of Odisha has started Odisha Millets Mission in kharif 2017. A report indicates that in the first year of its intervention in 2017-18, the yield has more than doubled and value of produce has more than trebled (Mishra 2020), but the reach of the mission in the first year has largely been on ragi and in less than 3.5 per cent of the area under millets in the state. One is made to understand that the spread of the mission is expanding. One hopes that the mission, notwithstanding the pandemic, does well in the coming years leading to a revival of these hitherto unforgotten, neglected and orphaned crops, which are now being considered as nutri-cereals and smartfood.

\section{CONCLUSION}

This has been an attempt to analyse and examine growth and decomposition for millets as also for each millet crop (particularly, ragi, jowar, bajra and small millets) from 196061 to 2019-20. Coinciding with the start of green-revolution in Odisha, the 1980s mark a reversal for millets with decadal growth since 1990s being negative and significant for production (except for 1980s when it was negative but not significant and 2000 s when it was positive and not significant) and for area. Our analysis shows that there has been a shift in area from millets around the 1980s, initially towards non-millet cereals (which, is largely paddy) and pulses and then in the 1990s, primarily to non-millet cereals and in the subsequent decades to pulses (and also to other crops groups as per our independent analysis). A silver lining is that there is perhaps an unmet demand for reviving small millets.

\section{ACKNOWLEDGEMENT}

The comments from an anonymous reviewer, P. Dash, N.C. Nayak, A.K. Padhee, N. Rath, H.S. Rout, B.K. Sahoo and from participants at National Workshop on Nutri-Cereals (Millets) Odisha 2019, 16 October 2019 and 39th Annual Conference of Indian Society of Probability and Statistics at Utkal University, Bhubaneswar, 21-23 December 2019 were helpful. This is part of the first author's PhD work under the supervision of the second author. Support from ICSSR, IGIDR, NCDS, OMM, TIGR ${ }^{2} E S S$ and WASSAN is acknowledged. The usual disclaimers apply.

\section{REFERENCES}

Ahmed, M.M., Sanders, J.H. and Nell, W.T. (2000). Newsorghum and millet cultivar introduction in Sub-Saharan Africa: Impacts and research agenda. Agricultural Systems. 64(1): 55-65.

Anderson, E. and Martin, J.H. (1949). World production and consumption of millet and sorghum. Economic Botany. 3(3): 265-288.

Basavaraj, G., Rao, P.P., Bhagavatula, S. and Ahmed, W. (2010). Availability and utilization of pearl millet in India. SAT e Journal. 8: 1-6.

Bhalla, G.S. and Singh, G. (2009). Economic liberalisation and Indian agriculture: A statewise analysis. Economic and Political Weekly. 44 (52): 34-44.

Bhat, S., Nandini, C. and Tippeswamy, V. (2018). Significance of small millets in nutrition and health-a review. Asian Journal of Dairy and Food Research. 37(1): 35-40.

Boyce, J.K. (1986). Kinked exponential models for growth rate estimation. Oxford Bulletin of Economics and Statistics. 48(4): 385-391.

Datir, R.P., Adil, S. and Sahare, A.S. (2018). Pearl millet: Boon in mineral deficiency: A review. Agricultural Reviews. 39(4): 327-332. 
FAO (Food and Agriculture Organization). (1995). Sorghum and Millets in Human Nutrition. Food and Nutrition Series No. 27. FAO, Rome, Italy.

FAO and ICRISAT. (1996). The World Sorghum Economies: Facts, Trends and Outlook. FAO, Rome, Italy and ICRISAT, Hyderabad, India.

Gari, J.A. (2002). Review of the African Millet Diversity. In IPGRI's Programme for Neglected and Underutilised Species.ed. International Workshop on Fonio, Food Security and Livelihood Among the Rural Poor in West Africa. IPGRI/ IFAD, Bamako, Mali. Pp. 19-22

Goel, K., Goomer, S. and Aggarwal, D. (2021). Formulation and optimization of value-added barnyard millet vermicelli using response surface methodology. Asian Journal of Dairy and Food Research. 40(1): 55-61.

Government of India. (2018). Notification of 10 April 2019 on NutriCereals, Ministry of Agriculture and Farmers Welfare, F.No. 4-4/2017-NFSM (E). The Gazette of India: Extraordinary. Part 1. Section 1. No. 133.

Government of Odisha. (2016a). Comprehensive revival of millets: Securing nutrition and surviving droughts in southern Odisha, Concept note for a consultation meeting on 27 January 2016 at NCDS, Planning and Coordination Department, No 635(8)/DCACS, dated 14 January 2016.

Government of Odisha. (2016b). Guidelines for implementation of "Special Programme for Promotion of Millets in Tribal Areas of Odisha", National Food Security Mission Cell, Directorate of Agriculture and Food Production, Odisha, Bhubaneswar, Letter No 40856 dated 28 November 2016.
Government of Odisha. (2020). Odisha Agriculture Statistics Report. Bhubaneswar: Directorate of Agriculture and Food Production, Odisha.

ICRISAT. (2019). Meet the Smart Food, 2019. ICRISAT, Hyderabad. Available: https://www.smartfood.org/smart-foods/.

Malathi, B., Appaji, C., Reddy, G.R., Dattatri, K. and Sudhakar, N. (2016). Growth pattern of millets in India. Indian Journal of Agricultural Research. 50(4): 382-386.

Mishra, S. (2020). Area, Yield, Production and Value of Produce under the Special Programme for Promotion of Millets in Tribal Areas of Odisha (Odisha Millets Mission), 2017-18, Phase-1. Nabakrushna Choudhury Centre for Development Studies, Bhubaneswar.

Narain, D. (1977). Growth of productivity in Indian agriculture. Indian Journal of Agricultural Economics. 32(1): 1-44.

Paltasingh, K.R. and Goyari, P. (2013). Analyzing growth and instability in subsistence agriculture of Odisha: Evidence from major crops. Agricultural Economics Research Review. 26 (conf): 67-78.

Rana, N. and Dahiya, S. (2021). Proximate Composition, In vitro Digestibility and Anti Nutritional Factors of Millets and Legume Grains. Agricultural Science Digest. DOI: 10.18805 lag.D-5248.

Rao, B.D., Bhaskarachary, K. Christina, G.D.A., Sudha Devi, G., Vilas, A.T. and Tonapi, A. (2017). Nutritional and health benefits of millets. ICAR-Indian Institute of Millets Research (IIMR): Hyderabad, India. 112. 